\title{
УДК-32
}

DOI: 10.17072/2218-1067-2019-1-15-23

\section{CREDIBLE COMMITMENT OR INCREDIBLE DEMANDS? EU CONDITIONALITY IN THE WESTERN BALKANS}

\author{
Tatiana Rudneva \\ National Research University Higher School of Economics
}

\begin{abstract}
The article deals with the EU's approach to conditionality policy in the Western Balkans. EU membership conditionality is generally believed to be one of the most effective tools at the EU's disposal to foster stability and democracy in the neighboring regions. However, the economic crisis that hit the Eurozone in 2007/2008 and the subsequent rise in Euroscepticism raised a question whether the incentives provided by the membership perspective are as convincing for new candidates and potential candidates as they were for the countries of Central and Eastern Europe. The article shows that, whilst the EU remains committed to the enlargement process in the Western Balkans, the transformations that the EU's approach has undergone have negatively affected the overall level of the Western Balkans's membership perspective.
\end{abstract}

Keywords: conditionality; enlargement; Western Balkans; democratization.

The European Union (EU) is grounded upon and set to promote common values and standards when it comes to such fundamental issues as human rights and political regime. To become a member of the EU, a state has to demonstrate both adoption of and subsequent adherence to the EU's principles of democracy, the rule of law and the respect for and protection of minorities (commonly known as Copenhagen criteria). In other words, the process of EU enlargement is governed by the principle of conditionality, which means that eventual membership for candidate states is conditional upon complying with EU-promoted norms.

After the success of EU conditionality in the Central and Eastern European countries (CEECs), the literature on Europeanisation was dominated by research pertaining to the impact of EU conditionality on democratic transitions in the candidate countries and the conditions under which democratic promotion on behalf of the EU turned out to be successful. The research comprised several comprehensive studies (Schimmelfennig, Sedelmeier, 2004; Vachudova, 2005) pointing out that the EU conditionality politics indeed played a substantial role in the establishment of democratic regimes in the CEEC region. In their groundbreaking works, Schimmelfennig and his colleagues (Schimmelfennig et al, 2003; Schimmelfennig, Sedelmeier, 2004) argued that the external incentives offered by the membership perspective helped to overcome the domestic obstacles for democratic reforms, thus ensuring that the democratic transition took place in the context it would otherwise not have done. Thus, credible conditionality in the form of external incentives was proven a necessary condition for successful democratisation. It was also established that in order to achieve sufficient conditions for democratic reforms, credible conditionality must be paired with favourable domestic conditions. For that, domestic costs related to the adoption of EU norms should be lower than the benefits associated with accession. However, after the successful 2004 enlargement round, the effects of EU conditionality ceased to be uniformly positive. Many believe that Bulgaria and Romania, who are now showing signs of backsliding, were admitted to the Union prematurely. As such, the conditions under which newer candidates will be allowed into the Union are likely to become even more demanding than usual. Moreover, there are growing concerns that the EU is suffering from 'enlargement fatigue' and is lacking the 'internal capacity' for further enlargement (Schimmelfennig, 2008). The concerns are understandable; with the EU expanding

(C) Rudneva T. S., 2019 
so rapidly, it is not clear whether a further increase in the number of members would allow the Union to act as a unified entity. In fact, the spike of Euroscepticism among some EU members and the European public may limit the capacity of the European Union to enlarge even in terms of signing and ratifying accession treaties. Every member state has a veto power, and some member states are even willing to put the decisions on further enlargements to national referenda. Phinnemore also points to the fact the narrative surrounding the enlargement is substantially different for potential and current candidates than it was for the CEECs, whose accession was framed as a "return to Europe", conveying a rather different message than the "enlargement fatigue' atmosphere prevailing now (Phinnemore, 2013).

In other words, there is a number of reasons to believe that for current and future candidates from the Western Balkans (WB), credibility of conditionality might be different than it was for the CEECs. The situation is further aggravated by the value of the second necessary condition, namely, the size of domestic adoption costs, being different for the WB region as well. With a heavy historical legacy, deficient separation of powers, infrastructural weakness and other deep structural problems, the domestic conditions in the region can be named all but favourable.

Previous research suggested that for EU conditionality to be effective, domestic adoption costs should be counterbalanced by credible incentives in the form of a membership perspective. With the growing salience of the 'enlargement fatigue' problem, there is a distinct possibility of the credibility of membership perspective being lower for the WB countries. With the domestic adoption costs higher than in the CEECs, lower credibility of the incentives could tip the overall balance to noncompliance with EU norms. In other words, whilst enlargement continues to be a major policy of the EU, there are growing concerns that EU conditionality is not equipped to foster democratisation further to the East (Bieber, 2011).

Guided by that problem, this article offers a theoretically informed analysis of the EU's approach to enlargement conditionality in the Western Balkans. Adopting a theoretical framework suggested by Schimmelfennig and others, who convincingly argue that the overall strength of political conditionality is determined by the size and credibility of conditional incentives (Schimmelfennig, Sedelmeier, 2004), the study examines the transformations of EU conditionality in the Western Balkans when compared to the CEECs and assesses the ensuing level of credibility. The concluding part discusses the possible implications of the level of credibility on the effectiveness of Europeanisation in the WB countries.

\section{Theoretical framework}

The process of EU enlargement is governed by conditionality, which means that the eventual membership for candidate states is conditional upon complying with EU-promoted norms. The logic behind conditionality is reinforcement by reward (Schimmelfennig et al., 2003), where the target states are rewarded if they adopt the EU norms. The most widely used model for explaining the effectiveness of conditionality is the External Incentives Model (EIM) (Schimmelfennig, Sedelmeier, 2004). The EIM captures a rationalist cost-benefit calculation on the part of the target governments. It starts with a 'domestic equilibrium' (the initial conditions in the country), which is then upset by the introduction of the possibility of material rewards that are conditional on the target governments' compliance with the norms of liberal democracy. If the benefits associated with the rewards exceed the costs of compliance, the target government, being a rational actor, is likely to choose to comply. The higher the benefits and the lower the costs, the more likely compliance is to take place. However, it is not only the size of the incentives that matters for compliance, but also their credibility.

Credibility of the incentives reflects how tight the rewards are tied to compliance and how plausible it is that compliance will indeed be rewarded with the promised benefits. Being the sole agent responsible for assessing compliance and allocating the rewards, the EU is the main bearer of credibility. In order to offer a country a credible membership perspective, the EU itself must be committed to the accession process. For that commitment to be credible, the EU should be able and willing to pay out the promised benefits if a candidate country fulfils the conditions. As such, for the purposes of a more detailed assessment of credibility, 
the article proposes to distinguish between the ability of the EU to deliver the rewards and the willingness to do so. Ability relates to the general capacity of the EU to enlarge and absorb new members (such as the ability to act in consensus as a unified entity). The lack of capacity to enlarge may affect the image of the EU as an agent capable of giving out the promised benefits. Willingness refers to the willingness of the EU to admit new countries in and readiness to judge their performance according to normative rather than politicised considerations. EU enlargement involves substantial costs not only on the part of the candidate countries, but also on the part of the EU, making it crucial for the EU to perceive the process as worthwhile. Additionally, the conditions according to which the EU judges the candidates' compliance should be clearly determined. When conditions are vague or ambiguous, they can become a 'moving target', jeopardising the candidate states' confidence that compliance with the conditions will definitely lead to acquiring the rewards.

Put differently, the aforementioned factors start from the assumption that compliance should be generally accomplishable and the rewards should be directly tied to compliance. If compliance is impossible due to the vagueness of the conditions or the lack of criteria what constitutes genuine compliance, credibility is open to question. The same is true if there is no certainty as to whether compliance with the conditions will yield the promised rewards.

\section{EU conditionality in Western Balkans: Size and credibility of incentives}

In order to adequately capture the characteristics and the implications of the EU's approach to conditionality in the WB region, the article will assess four areas identified as being of crucial importance for credible and effective conditionality: 1), willingness of the EU; 2), ability of the EU; 3), determinacy of conditions; 4), size of rewards.

Willingness. During the last decade, the EU had to face a number of serious challenges, which unravelled grave problems within the Union itself. The economic crisis in the Eurozone since 2007/2008, the refugee crisis, democratic backsliding in member states and, most recently, Brexit - all these challenges prompted the European population and the member states to question their support for the big 'unified Europe' project that the EU ultimately represents. With growing concerns about the 'enlargement fatigue', which could potentially affect both the ability as well as the willingness to enlarge, the obvious question is whether the credibility of EU commitment has diminished. A decline in the attractiveness of European integration in general inevitably affects the attractiveness of external European integration in the form of European enlargement as well. However, analysing the willingness of the EU to enlarge, it is important to remember that the goal of EU membership conditionality is not to enlarge as such, but rather to promote stability and democracy in the neighbouring regions.

EU membership conditionality has been found one of the most effective tools for peaceful external stabilisation and democratisation the EU has at its disposal. As Vachudova rightly notes, if the EU wanted to propose the Western Balkans a different kind of association rather than full integration, it would have done so (Vachudova, 2014). By promising benefits that fall short of a membership perspective, the EU would have lowered the costs of stabilisation efforts in the region, but only lowering the effectiveness of those efforts at the same time. Instead, the EU remains committed to enlargement as enlargement remains an efficient way to foster democratic regimes in the nearby regions, which still falls within the EU's geopolitical interests. However, moderate support for the enlargement project among the EU public and mixed attitudes among the member states, paired with more difficult initial conditions in the current candidate states when compared to the CEECs, point to the possibility that for the Balkans the pre-accession process may take longer or even lose some (if not all) of its efficiency. There is a general consensus that credible membership perspective is necessary for compliance, but a rather vague understanding where the tipping point between credible and not credible might be. That said, the successful accession of Croatia in 2013 is a piece of empirical evidence suggesting that for the WB region in general, membership perspective is still credible enough.

So far, the focus has been on more theoretical accounts of possible changes to the level of the EU's willingness to enlarge. Let us now turn to the actual practice of EU enlargement when it comes to the West- 
ern Balkans. The European perspective for the WB region was first officially recognised by the EU during the Feira European Council in June 2000. A year before that, in June 1999, the EU launched the Stabilisation and Association process for the Western Balkans (SAP), promoting progressive partnership for Balkan countries with the ultimate goal of EU membership, provided the Copenhagen criteria are met. The European perspective was reaffirmed at the Summit of Zagreb in November 2000 and the Summit of Thessaloniki in June 2003. After the 'enlargement fatigue' started to hit the EU following the accession of Bulgaria and Romania, the European Commission again reaffirmed the organisation's commitment to WB enlargement by issuing a communication entitled «Western Balkans: enhancing the European perspective». Even after the economic crisis of 2008, the EU continued to engage with the WB countries, welcoming Montenegro as an official candidate in 2010 and Serbia in 2012. In 2013 came the ultimate evidence of the EU's commitment, when Croatia managed to successfully join the EU as the first country from the WB region. In 2014, eleven years after the original Thessaloniki EU-Western Balkans summit, the EU reinforced its commitment by holding an EU-Western Balkans Ministerial Conference in Thessaloniki. The leaders of WB countries and EU representatives met later that year at the Conference of Western Balkan States in Berlin, where the so called Berlin Process was launched, resulting in a continuing series of annual WB summits. The year of 2018 was marked by a number of important events. In February, a Strategy for the Western Balkans was issued, reconfirming the EU's commitment to a credible enlargement perspective of the Western Balkans and setting a possible accession date for Serbia and Montenegro at 2025. In May, EU-Western Balkans Summit took place in Sofia, followed by a Western Balkans Summit in July in London. Judging by numerous reaffirmations on the EU's part of its commitment to the enlargement process, growing partnership and cooperation with the WB countries under the framework of SAP, the accession process and elsewhere, the accession of Croatia and the progress of the remaining candidates and potential candidates, there is not much evidence to suggest that the EU has not been committed, in word or deed, to its Western Balkans enlargement.

In the light of the general Euroscepticism crisis, enlargement may look less attractive than in the past, but that is not to say that the WB countries as a region are not welcome in the EU. Unlike Turkey, whose candidacy was opposed by a number of member states from the very beginning of the pre-accession process, the Western Balkans never had their eligibility to participate in the enlargement process questioned. The EU consistently reaffirmed its commitment to the Western Balkan enlargement. However, it is important not to forget that for the EU, the primary goal of the Stabilisation and Association process in the Western Balkans is stabilisation. Association is a means to achieving that goal. The EU is not 'reuniting' with the Western Balkans as it was the case with the CEECs (Phinnemore, 2013), but rather stabilising and democratising the region. In other words, the EU is not interested in uniting with the Western Balkans as such; it is interested in uniting with stable democratic Western Balkans. Whether this is something the Western Balkans can deliver is another question.

Ability. Another factor influencing the credibility of the incentives is the ability of the EU to give out the promised rewards. In light of the general Euroscepticism moods, the ability of the EU to give out the rewards is determined by its ability to act as a single entity. To date, the EU consists of 28 member states ${ }^{1}$. When it comes to enlargement, each member state has a veto power. Theoretically, a single member state that opposes the idea of a certain candidate country joining (due to, for example, unresolved bilateral issues) can block the accession of the candidate state even if the remaining 27 member states approve the accession. The violent dissolution of Yugoslavia left many borders legally unsettled, making the ability of the EU to act as a single entity all the more important due to a sheer number of potential border disputes amongst the WB countries.

For Croatia, the first WB country to join the EU, the accession process was protracted by a border dispute with the neighboring Slovenia, who joined the EU earlier in 2004. In 2008, Slovenia used its veto power to block the accession negotiations between Croatia and the EU. Explaining its unilateral decision to block a substantial number of negotiation chapters, Slovenia argued that maps and documents submitted by

\footnotetext{
${ }^{1}$ The number of the member states is soon to change to 27 due to Brexit.
} 
Croatia to the EU as part of the preparation for accession contained clear referrals to the borders between Slovenia and Croatia, which the Slovenian authorities perceived as an attempt to pre-judge the borders. Despite the fact that the EU repeatedly insisted that the border dispute between the two countries was an exclusively bilateral issue and should not have come up in the accession negotiations, Slovenia's veto still managed to considerably delay the progress of Croatia's accession.

In 2016, when Croatia itself was a member state, it tried to block the opening of new chapters in accession negotiations of another candidate state from the WB region, Serbia. This time, the reason was a dissatisfaction with the treatment of the Croatian minority in Serbia and the provisions of the Serbian law on universal jurisdiction on war crimes. Again, Croatia was the only member state that argued against Serbia's advances in the accession process, and acted so without the support of the EU. Beside Slovenia and Serbia, Croatia has unsettled disputes with Montenegro, a candidate state, and Bosnia and Herzegovina, a potential candidate. With their actions, Slovenia and Croatia set a dangerous precedent, when the candidate countries can no longer be confident that all the member states will act in a "European spirit" and that the accession talks will not become a platform for resolving politicised bilateral problems. As the current frontrunners in the accession process, Serbia and Montenegro, also have ongoing disputes with their neighbours, the number of disputes potentially stalling the accession process is likely to rise even further with their accession.

Another bilateral dispute that severely affected the progress of a candidate country is a controversial FYROM-Greece name issue. Within Greece itself, the name Macedonia is used to refer to a region constituting a part of Greece. Despite Macedonia's assurances that the name does not presuppose territorial claims, Greece remains objected to the name of Macedonia being used by the FYROM. Again, Greece is the only member state having such objections. The EU does not object to the name of Macedonia and is only concerned with the issue as neither Greece nor Macedonia would drop their claims to that name.

An interesting example of a situation when the EU did choose to override the member states' objections is signing and ratifying of the Stabilization and Association Agreement (SAA) with Kosovo. Habitually, the SAAs are ratified by the member states, which in the case of Kosovo would have been problematic given that some member states do not recognize Kosovo. In order to bypass the issue, the EU changed the usual procedure and allowed the SAA to be ratified by the European Parliament only. That may have increased the credibility of a membership perspective for Kosovo, but does raise concerns about preferential, rather than impartial, treatment. For example, the SAA with Serbia was signed in 2008, but went into force only in 2013, after all the member states have ratified it. For Kosovo, the same process proved to be a matter of months, rather than years.

The lack of a common approach to bilateral issues and the failure of the EU to consistently speak with a single voice cast doubt on the reputation of the EU as an agent capable of giving out the promised benefits. In the Western Balkans, unresolved bilateral issue is an almost inevitable legacy of the violent dissolution of Yugoslavia. In that light, the fact that bilateral issues have not been kept out of the enlargement process as originally intended, provides for a source of uncertainty, when candidate countries can no longer be sure that they will be judged solely on their performance in the Copenhagen criteria area.

Determinacy of conditions. If anything, the conditions for the Western Balkans are more determinate than they were for the CEECs. The most important thing the EU did in this area was the introduction of the system of benchmarking. For each candidate the EU specifies a set of conditions to be fulfilled in order to move to the next stage of the pre-accession process. The EU reviews the progress the candidate country has made during the previous year in annual editions of Regular Reports, documents specifically designed to give a clear assessment of the progress made and an indication of what still needs to be done in order to further proceed with the accession. The obvious advantage of benchmarking is that it intensifies the principle of conditionality, not only tying the rewards to the fulfilment of conditions, but also facilitating the assessment when it comes to compliance. When conditions are clear and definite, it is easier to assess whether the candidate country has indeed met the conditions. As such, clarity reduces the likelihood of a scenario where the candidate country has met the conditions, but is not considered by the EU to have done so, and vice versa. It can be viewed as a safety measure for both the target country, which needs to be sure that their compliance 
will definitely be rewarded, as well as for the EU, which understandably tries to avoid the problem of fake compliance. However, despite the fact that the EU does strive to clearly determine conditions, the accession process of Serbia is considerably hindered by vagueness on the part of the EU regarding the issue of Kosovo.

«Normalization of relations between Serbia and Kosovo» is one of the most important conditions Serbia has to fulfil. The condition has been met quite negatively by both the general population and the political elites of Serbia. Kosovo by itself is a sensitive issue for Serbia, but this particular situation is aggravated by the fear that «normalization of relations with Kosovo» presupposes official recognition thereof, which the authorities of Serbia strongly oppose. That is not to say that the conditions pertaining to "normalization of relations with Kosovo» are not clearly worded by the EU. The EU perceives of normalization of relations as a very comprehensive and detailed process, comprising a whole range of measures, including recognition of university diplomas, resolution of the issue of license plates and so on. Recognition of Kosovo does not feature in any of the official documentation as a condition for Serbia's accession. However, the issue of vagueness and possible misinterpretation still remains, resulting in a rather cautious approach of the Serbian government to compliance both in this area and in general. What we are witnessing in the Serbia-Kosovo situation is not exactly a failure of the European Union to clearly articulate what the conditions for accession are, but rather its failure to articulate what they are not.

Looking back, the ambiguity of «normalization of relations» is not a new problem in the history in the European integration. It substantially tainted the EU-Turkey accession process more than a decade before the Kosovo situation. As a prerequisite for the opening of the accession negotiations, Turkey was required to sign and implement the Additional Protocol to the EU-Turkey Customs Union Agreement. The purpose of the Additional Protocol was to extend the Customs Union to the ten new member states, who joined the Union in 2004. Turkey did sign the Additional Protocol, declaring at the same time that this move should not be interpreted as an official recognition of Cyprus, which joined the EU along with nine other states in 2004 and which Turkey refuses to recognize for historical reasons. Turkey also refused to implement its obligations to Cyprus undertaken when signing the Additional Protocol. A discussion of the legal consequences of the Additional Protocol followed, with no clear answer as to whether participation in the same Customs Union means recognizing Cyprus as a sovereign state. Several EU member states urged Turkey to recognize Cyprus, strongly questioning the possibility of joining the EU whilst not recognizing one of the EU states. Their concerns, and Turkey's concerns as well, are more than understandable, notwithstanding the fact that recognizing Cyprus was not an official precondition for joining the EU. To sum up, the determinacy of conditions requirement has not always been adequately met, despite the ongoing efforts and the introduction of benchmarking.

Size of rewards. The factor of the size of the rewards stems not so much from research on EU enlargement, but rather from the research into the role of political conditionality in external democratization in general. That is due to the fact that membership in an international organization is one of the biggest rewards the targeted country can get in case of compliance. It has been empirically shown that political conditionality tends to be considerably less effective if a membership perspective is absent (Schimmelfennig, 2008). In that respect, the size of the rewards helps to override the size of domestic adoption costs.

For all EU candidates, the size of the ultimate reward, that of EU membership, is the same. That led to a general assumption when researching the effectiveness of EU conditionality that the variable of the size of rewards is controlled for. However, one has to note that the EU generally starts to exert its political pressure before the target country receives the official status of a candidate. Receipt of the status is by itself conditional on a certain degree of adherence to the Copenhagen criteria. In that respect, the target countries are subjected to the policy of conditionality even before the process of accession becomes official. That did not produce much of a difference for CEE countries, who rarely experienced problems when achieving the status of a candidate. For the WB countries, burdened with limited statehood, history of ethnic strife and low levels of economic development, the situation is quite different. Notwithstanding the fact that the ultimate reward for EU candidates from the Western Balkans remained the same, the pre-accession process underwent considerable changes. 
As Vachudova notes, longer periods of conditionality are needed in order to achieve stable behavioral compliance (as opposed to legal compliance only) (Vachudova, 2014: 132). Given such obstacles as limited statehood and weak administrative, financial and technical capacities, behavioral compliance in the Western Balkans may prove no less problematic than the introduction of the necessary reforms on a legal level. This might be the reason behind the EU's decision to engage with the Western Balkan countries in the Stabilization and Association process (SAP) long before the countries are officially recognized as candidates. To position the SAP within the framework of the accession process, the EU introduced the status of "potential candidate" for those countries that are involved in the SAP, but are not yet candidates. In that respect, earlier stages of the SAP constitute a preparatory stage for the accession process. Once the official accession process begins, the SAP continues to define the framework for European integration, ending only when the target country joins the EU.

The introduction of the SAP added new phases to the pre-accession process. In the official accession process, there are five crucial phases: 1), application; 2), recognition as a candidate state; 3 ), opening of negotiations; 4), official closure of negotiations; 5), signing of the accession treaty (Böhmelt and Freyburg, 2013). However, in case of the Western Balkans the accession process is extended with a number of preaccession phases, such as a) inclusion of the target country to the SAP; b) opening of negotiations (preparing for the signing of the Stabilization and Association agreement (SAA); c) initiation of the SAA; d) signing of the SAA. When the SAA comes into force and the target country demonstrates its adherence to the conditions specified in the SAA, the target country may apply for a candidate status and become an official candidate.

Whilst Association Agreements (also known as Europe Agreements) by themselves are not a new phenomenon, the SAAs that are signed with the Western Balkan countries under the framework of the SAP clearly constitute not a partnership agreement alone, but a necessary part of the pre-accession process. One cannot enter the accession process without participation in the preparatory part. As such, the phases leading to the signing and implementing of the SAAs make for additional steps on the path to joining the EU. However, until the country is officially a candidate, the ultimate reward for compliance is not membership, but a prospect of membership only. If the candidate country complies with the conditions as required by the EU, it will be rewarded with membership in the European Union. If the country complies with the criteria during the earlier stages of the pre-accession process, it will be rewarded with the option of participating in the official accession process. In that respect, the pre-accession process of the WB countries is characterized by two distinct properties: a) it is lengthier and contains more steps on the path to the European integration; b) during a substantial part of the pre-accession process the reward is lower than that of a membership.

What is also important to note is that as a result of prolonging the pre-accession process with the SAP, there are certain inconsistencies regarding the EU's approach as to what conditions are due to be satisfied at what stage. If Croatia had to meet the condition of full cooperation with the International Tribunal in order to open membership negotiations (and already having a candidate status), Serbia and Montenegro were asked to satisfy the same condition at a much earlier stage. As such, the reward for satisfying what essentially is the same condition was much lower for Serbia and Montenegro than it was for Croatia. In other words, not only can the size of the final benefit be considered different for at least a part of the pre-accession process of the Western Balkans when compared to the CEECs, but also the size of intermediate rewards can substantially differ. As the size of the rewards is an important factor in the overall level of credibility, there is a distinct possibility that the described changes to the pre-accession process could carry consequences for the effectiveness of EU conditionality in the Western Balkans.

With its conditionality policy, the EU seeks to promote democracy and foster peace and stability in its direct neighborhood. However, the project of European integration, let alone external European integration, is facing challenging times. EU membership conditionality is generally considered to be a powerful and 
effective tool employed by the EU in order to foster democratization outside its borders. In Europeanisation literature, much research has been done into the transformative power of the EU and democratization in Central and Eastern European countries. Researchers tend to agree that the EU with the incentives provided by the possibility of accession to the Union indeed played a catalytic role in democratic consolidation in the aforementioned countries (Schimmelfennig et al, 2003), and that credible membership conditionality was an individually necessary variable explaining the success of democratization (Schimmelfennig et al, 2006). However, after the success of the 2004 enlargement round, the EU's approach to membership conditionality altered. With the credibility of the membership incentives questioned, the transformative power of the European Union may not prove strong enough to overcome the difficult historical legacy of the Western Balkans.

This article assessed the size and the credibility of membership incentives building up on a theoretical framework set forward by the External Incentives Model, widely used in Europeanisation research. Assessing the differences between the EU's approach in the Western Balkan and the CEECs and evaluating them against a number of factors identified in previous research, it was established that candidate countries are indeed faced with more uncertainty when it comes to their membership perspective. Whilst the EU remains committed to the enlargement process as it still falls under the EU's interests, the ability of the EU to speak with a single voice is questioned. The enlargement process serves the EU's interests only as long as it helps to foster peace and stability in its direct neighborhood. To safeguard itself from admitting unprepared countries in, as some argue was the case with Bulgaria and Romania, the EU introduced a number of additional phases to the pre-accession process, making the process lengthier and the membership perspective even more remote. At the same time, the EU strives to counterbalance the effects of the declining credibility by showcasing its commitment. However, proclaimed commitment is not the only factor that determines the overall level of credibility, which is still lower than it was for the CEECs. The EU is prepared to welcome the Western Balkans, but only after they have achieved a sufficient level of democracy and stability. On the one hand, the rewards are tied to compliance, which is the epitome of conditionality policy. On the other hand, given the initial conditions in the Western Balkans, achieving democracy and stability is likely to be a long and difficult process. After years of participating in the SAP, the Western Balkans are still suffering from deficient institutions, clientelism, organized crime and other deep structural and behavioral problems.

That is not to say that the WB countries did not comply with the EU's demands throughout the SAP. However, not least because the EU chose to pressure for compliance in other areas, such as cooperation with the International Tribunal or normalization of relations with neighboring countries, most of the lingering, Balkan-wide problems have not been resolved. Arresting a war criminal or signing a normalization agreement may require a certain leader coming to power, but it is at the end of the day a single-action episode of compliance. Compliance in other areas, however, may require longer periods of complex reforms and their implementation. As such, an adequate resolution of structural problems requires time no less than effort. In other words, after years of the SAP and considerable, although not sufficient, compliance with a number of the EU's demands, the Western Balkans still have a long way to go, with membership perspective being real, but worryingly distant. 


\title{
References
}

Bieber, F. (2011) 'Building Impossible States? State-Building Strategies and EU Membership in the Western Balkans', Europe-Asia Studies, 63(10), pp. 1783-1802, DOI:10.1080/09668136.2011.618679.

Böhmelt, T., Freyburg, T. (2013) 'The temporal dimension of the credibility of EU conditionality and candidate states' compliance with the acquis communautaire, 1998-2009', European Union Politics, 14(2), pp. 250-272, DOI:10.1177/1465116512458164.

Phinnemore, D. (2013) 'The Stabilisation and Association Process: A Framework for European Union Enlargement?' in Elbasani, A. (ed.) European integration and transformation in the Western Balkans: Europeanization or business as usual? Abingdon: Routledge, pp. 22-35.

Schimmelfennig, F., Engert, S., Knobel, H. (2003) 'Costs, commitment and compliance: The impact of EU democratic conditionality on Latvia, Slovakia and Turkey', JCMS, 41(3), pp. 495-518, DOI: 10.1111/1468-5965.00432.
Schimmelfennig, F., Engert, S., Knobel, H. (2006) International Socialization in Europe: European Organizations, Political Conditionality, and Democratic Change. Basingstoke: Palgrave Macmillan.

Schimmelfennig, F., Sedelmeier, U. (2004) 'Governance by conditionality: EU rule transfer to the candidate countries of Central and Eastern Europe', Journal of European Public Policy, 11(4), pp. 661-679, DOI: $10.1080 / 1350176042000248089$.

Schimmelfennig, F. (2008) 'EU political accession conditionality after the 2004 enlargement: consistency and effectiveness', Journal of European Public Policy, 15(6), pp. 918-937, DOI: $10.1080 / 13501760802196861$.

Vachudova, A.M. (2005) Europe Undivided: Democracy, Leverage, and Integration after Communism. Oxford: OUP.

Vachudova, A.M. (2014) 'EU Leverage and National Interests in the Balkans: The Puzzles of Enlargement Ten Years On', JCMS, 52(1), pp. 122-138, DOI: $10.1111 /$ jcms. 12081 .

\section{Информация об авторе}

Руднева Татьяна Сергеевна - аспирант Национального исследовательского университета «Высшая школа экономики». E-mail: trudneva@hse.ru (ORCID: 0000-0001-5201-3338, ResearcherID: U-7101-2017).

Статья принята к печати: 15.12.2018

\section{НАДЕЖНЫЕ ОБЯЗАТЕЛЬСТВА ИЛИ НЕВЫПОЛНИМЫЕ ТРЕБОВАНИЯ ДЛЯ КАНДИДАТОВ? РАСШИРЕНИЕ ЕС НА ЗАПАДНЫХ БАЛКАНАХ}

\author{
Т. С. Руднева \\ Национальный исследовательский университет «Высшая школа экономики»
}

\begin{abstract}
Аннотация
В статье рассматривается подход Евросоюза к применению политики кондициональности в регионе Западных Балкан. Лежащая в основе расширения Евросоюза политика кондициональности считается одним из наиболее эффективных инструментов внешней стабилизации и демократизации. Тем не менее, экономический кризис и последовавший за ним рост евроскептицизма поднимают вопрос, сохранили ли свою убедительность стимулы, связанные с перспективой присоединения к Евросоюзу, для новых стран-кандидатов и потенциальных кандидатов в сравнении с кандидатами из стран ЦВЕ. В результате исследования сделан вывод, что Евросоюз продолжает считать расширение на Западные Балканы своей приоритетной задачей. Несмотря на это, изменения, произошедшие в подходе Евросоюза, действительно негативно повлияли на уровень убедительности перспективы присоединения стран Западных Балкан к ЕС.
\end{abstract}

Ключевые слова: кондициональность; расширение ЕС; Западные Балканы; демократизация. 